\title{
Kongressatletene kommer
}

\author{
«Kongressen danser!» het det om Wienerkongressen, der man brukte tiden på festligheter \\ istedenfor problemløsning. Men på kongresser dominert av en overflod av data - dårlig \\ presentert - hadde det kanskje vært på sin plass med en svingom?
}

Med økende bruk av teknologi skjer det en dramatisk økning i datamengden som hver forsker genererer. Da øker problemene med å presentere dem på en forståelig måte. På én eneste kongress kan det bli lagt frem data som er resultatet av over tusen årsverk. Hvordan i all verden skal man da klare å formidle alle de nye resultatene til en forsamling av kongressdeltakere i løpet av 4-5 dager? Det er bare én ting å gjøre: Opp med dampen, jenter og gutter. Snakk fortere, ha flere data per bilde, bruk flere typer grafikk - og spill ikke tiden med unødvendige pauser!

Dette grunnleggende problemet har vi hatt i flere tiår, mens metodene til å presentere alle de nye resultatene har vekslet. | 1980-åren flimret lysbildene så fort under presentasjonen at tilskuerne knapt nok så om de sto rett eller opp ned. Siden kom de såkalte transparentheltene, der delvis uleselige foiler flagret gjennom prosjektørene. Men først da powerpointpresentasjonene kom på banen ble det virkelig tett med flimrende kurver og fotografier. For å få plass til alt ble teksten gjort liten og tabellene enda mindre - men fargene desto mer flerfoldige. Fortsatt har powerpointatletene et godt nakketak på kongressdeltakere, særlig hvis de står med ryggen til og snakker.
Alt dette tullballet skjønte Carl W. Janssen jr. (1929-2002). Han var opprinnelig fra Orkdal, men i en årrekke ansatt som gastrokirurg ved Haukeland universitetssykehus. Alle kjent Calle - godlynt, snill og original og (som hos en del kirurger) med en utrolig sterk og buldrende stemme. Sa han noe i en forsamling, snudde alle seg for å se hvem det var.

Allerede i 1988 avslørte han hele denne humbugen. På seminarer og møter var det i hovedsak to typer mennesker: De som talte og ikke brydde seg om å kommunisere med tilhørerne, og de som satt i salen og hørte på og var utsatt for alvorlige lidelser. Ikke minst innså han hvor deilig det var å reise fra seminaret - ta toget gjennom naturskjønne omgivelser til Bergen og få en «nuss» av sin kone når han gikk av på endestasjonen. Det gjorde kongressreisen virkelig meningsfull.

\section{Ole Didrik Lærum}

ole.laerum@gades.uib.no

Ole Didrik Lærum (f. 1940) er professor (adj.) ved Københavns Universitet og professor emeritus ved Universitetet i Bergen

\section{På Bergenstoget - tanker etter et seminar}

Carl W Janssen Jr Overlege, dr med, Kirurgisk avd, Haukeland Sykehus, N-5021 Bergen Nord Med 1988; 103: 181-2.

Det er aften på Bergens-toget. Fjellsidene og silhuettene er ennå tydelige i mørket mot den klare himmel. Det passerer tallrike glade minner om ski- og fotturer gjennom mange år, sist var det på Ustetind for to uker siden.

Min stemning står likevel i moll i aften. Årene er gått, og jeg er brutalt minnet om at aktivitetene nå må begrenses. Jeg er på vei hjem fra et møte, et skandinavisk seminar denne gang. To dager med 45 fremførte foredrag, 11 foredrag «read by title» og 13 sesjoner med diskusjon. Jeg har sett mellom 500 og 1000 tabeller og figurer som lysbilder. Alt har foregått på engelsk.

En lang togreise gir en arbeidsfred jeg sjelden får på kontoret. Jeg leser sammendragene og mine notater, jeg ordner papi- rene med tanke på arkivering, hva jeg skal bruke $i$ undervisningen og eventuelt $i$ våre rutiner.

Men jeg får det ikke ordentlig til. De fleste foredragsholdere har henvendt seg til meg som om min hjerne og min forstand skulle ha en helt annen kapasitet enn hva tilfellet virkelig er. Meget har foregått disse to dagene som jeg ikke har fått med meg.

\section{Hva ville foredragsholderne meddele?}

Det var ofte jeg ikke engang fikk tak på hva foredragene egentlig dreide seg om. Ikke mange av de 45 foredragsholdere la vekt på en innledning som «Hvorfor har vi gjort det?» Og slett ikke alle dem som utbrøt «First slide, please!» ennå før de var nådd talerstolen. Og uten kjennskap til bakgrunnen og motivasjonen for en undersøkelse er tilhøreren latt tilbake med et slags: «Hva er det egentlig han vil fortelle meg?»

Om mange var sparsomme med sin introduksjon, så hadde de fleste en desto større bredde $\mathrm{i}$ fremstillingen av sine resultater. Jeg kan forsikre, det manglet ikke! Jeg prøvde å henge på så godt jeg kunne. Men sorry, jeg klarer ikke bilde etter bilde med tallkolonner eller diagrammer og som skifter, ja, jeg tok tiden enkelte ganger, det var opp til 5 ganger i minuttet. Man henvender seg til meg som om jeg er en type PC med en ubegrenset kapasitet for input. Men min hjerne har aldri vært slik, og bedre blir den ikke med årene. 
Når det ikke var helt klart hva foredragsholderen egentlig ville meddele, så var det heller ikke alltid lett å forstå hva bildene hans fremstilte. Det var just ikke mange bilder hvor vedkommende hadde unnet oss tilhørere en forklarende tekst, slik regelen er med figurer og tabeller når vi sender et manuskript til publikasjon. Når det på y-aksen står «\%-aktivitet» og på x-aksen er fire kolonner merket: «Fase I Fase II Fase III Fase IV» som den eneste forklaring på figuren, ja, så skal det ikke være mye villrede, enn si den minste absence, før det hele er uten mening for en tilhører.

I en skriftlig fremstilling har vi kun våre ord å meddele oss med. I en muntlig fremstilling derimot, har vi i tillegg fordelen at vi kan fremheve våre ord og meninger med vårt tonefall, vår mimikk og hele vårt kroppsspråk. Det er rett ikke mange som spiller på slike strenger for å få frem sitt budskap.

\section{Fjetret av bilder}

$\mathrm{Ja}$, enkelte er så fjetret av sine bilder at de likegodt vender seg fra forsamlingen og snakker til lerretet. Da blir det ikke mye plass til mimikk og kroppsspråk. Man må ha meg unnskyldt, men en slik foredragsholder bringer så lett mine tanker til enkelte bisettelser, hvor det kan skje at en går frem og taler til båren og den avsjelete med ryggen vendt mot menigheten.

Andre får ikke øynene ut av manuskriptet. Da blir det heller ikke mye mimikk og ofte sparsomt med tonefall. Jeg tror det er noe av det kjedeligste mennesker kan oppleve, det å få en vitenskapelig tekst fremført som høytlesning. For auditoriet ville det være å foretrekke om vedkommende mangfoldiggjorde og delte ut sitt manuskript og så erklærte ti minutters stillhet for innenatlesning.

Aftentimene går. Det er hele tiden en rytme $i$ toget og samtidig en stadig avveksling, nå i mørket over fjellet er det i første rekke broene, tunnelene og stasjonsbygningene. Det er en situasjon som både gir ro og flukt for ens tanke.

Det er noe i dette som ikke stemmer. Når vi i den medisinske verden skal meddele våre observasjoner til andre i skrevne ord, så stilles det meget strenge krav til formalitet og kvalitet. Jeg tenker på mine håndbøker som Medical writing, Style manual for biological journals og andre, og på den mappen jeg har med Instruction to authors fra tidsskriftene. Og vi kan ikke nok arbeide med våre manuskripter for å få vårt budskap klart frem.

\section{Hvor lærer vi muntlig fremstilling?}

Men hva gjelder for en muntlig fremstilling av forskningsresultater? Det er fakultetene som har det overordnede ansvar for kvali-

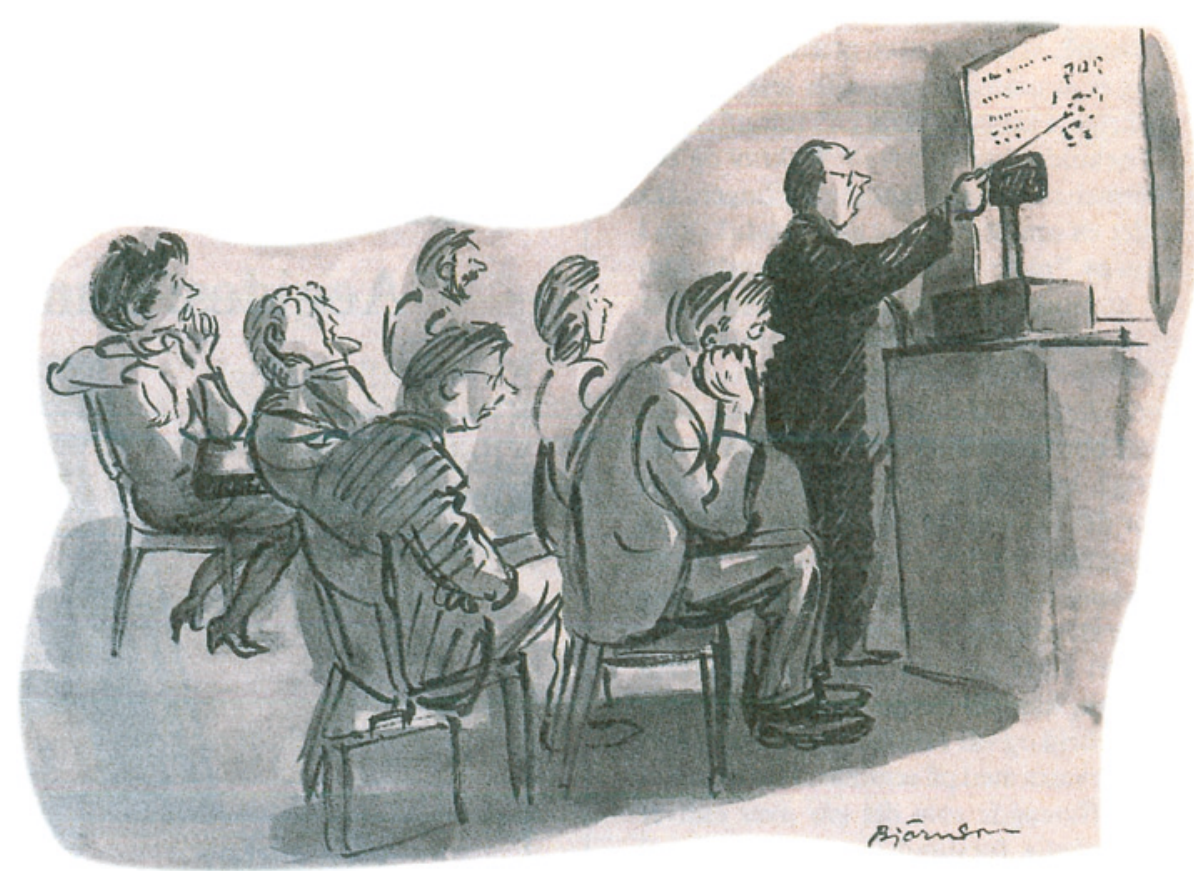

Enkelte foredragsholdere er så fjetret av sine bilder at de likegodt vender seg fra forsamlingen og snakker til lerretet. Tegning Sven Björnson, Sverige

teten i vitenskapelige arbeider og fremstillinger. Hva sier de om form og innhold $i$ et foredrag, ja, ikke vet jeg. Jeg tenker på disputasene som et korrektiv til forskning og meddelelse. Da er det ikke måte på som doktoranden må stå til rette for sine skrevne ord. Men aldri har jeg hørt at noen får et korrektiv for sine prøveforelesninger. Det er nesten så man fristes til en sarkasme, at kravet til en prøveforelesning i dag er at man kan tale, eller lese sitt manuskript, i sammenheng i 45 minutter.

Forholdet har en parallell i krav og bedømmelser for akademiske stillinger. Da er det en omfattende og god produksjon i form av «papers» som er avgjørende. Om det muntlige kan det derimot hete: «Det vil bli lagt vekt på en bred undervisningserfaring.» I det ligger det ingen kvalitetskrav, derimot et postulat at den muntlige form blir bedre med erfaring. Men er det riktig? Jeg husker fra min egen studietid hvor det var enkelte lærere som var slette pedagoger, og hvis forelesninger var en prøvelse. Og bedre med årene ble de ikke akkurat, snarere tvert imot!

Stort verre enn det man nå risikerer å oppleve, kan det neppe være. Vi forlater vårt arbeid og vår familie og setter oss $i$ utgift for å være med på seminar. Her møter vi en stoffmengde som det går over enhver menneskelig forstand å persipere. Og vi blir presentert for fremstillinger som aldri hadde passert hvis de var vurdert på forhånd. Det er en pedagogisk utfordring å skulle meddele sitt budskap i løpet av ti minutter til en forsamling av uinnvidde, men tross alt intelligente mennesker. Det er ikke alle som virkelig griper denne utfordringen.
Det unnslipper meg et hjertesukk - er lysbilder på et lerret og med en lyspil i et dunkelt lokale nå nærmest obligat for kommunikasjon mellom leger? En velformet tale og noen stikkord med kritt på en tavle («chalk and talk») er ofte meget virkningsfullt for å fange et auditorium. Men tavlen fantes ikke der jeg var disse dagene.

Toget er i ferd med å komme ned fra fjellet, og vi ser lys i enkelte hjem langs banen. Der sitter det mennesker som er godtfolk som meg. Om de på to dager hadde hørt 45 slike foredrag knyttet til sitt yrke, kanskje de også ville gå til sitt arbeid i morgen og gjøre akkurat det samme som gjorde for to dager siden.

Min mollstemning gir seg etter som den ene tanke avløser den andre. Langs Sørfjorden lar jeg papirene ligge, og nå er det et ord av Ibsen som kommer for meg, fra Peer Gynt, scenen i dårekisten i Kairo, hvor Begriffenfeldt sier:

«De halvfjerdssindstyve fortolkeres krets, den er nylig forøket med hundre og tress.»

Det er nok det som er meningen med seminarer, men fortolkernes krets blir nok ikke særlig større med den form som slike seminarer nå kan ha.

Om en liten time er vi inne. Jeg tror så visst at min kone vil smile slik bare hun kan når vi møtes på plattformen. Og i morgen venter igjen en travel dag på avdelingen. Vi skal nok stå på, tross alt. 